The measure provides that the general plan secured by the Allison Commission for its guidance in the placement of the Allison Memorial be followed in the enlargement and improvement of the grounds. It provides that the Executive Council serve without pay as agents for the acquisition of the grounds and as commissioners for the performance of the work. The Executive Council is granted authority to acquire any or all grounds within an area ample for a finished work unequalled in landscape value in any American capital and never excelled in economy in any public work. It is the final touch in the purpose of Gen. Grenville M. Dodge to make of the tribute to Senator Allison not only an ideal of art, but a step forward in the annals of all Iowa constructive building and business.

\title{
JUDGE CALDWELL ON HENRY CLAY DEAN.
}

Hon. Henry Clay Caldwell communicated his thoughts as to the sketch of Rev. J. W. Cheney on Henry Clay Dean to the author of that sketch, and we have requested the privilege of reproducing Judge Caldwell's letter :

2195 West 24th St., Los Angeles, Cal. Nov. 28, 1912.

My Dear Cheney:

I have just finished reading your biography of Henry Clay Dean in the last number of the Annals, ${ }^{1}$ and write to compliment you upon it. It is far and away the best biography of that wonderful man that has been written.

I esteem myself something of a judge of men and their abilities, and, in my opinion, Dean was the greatest natural orator and reasoner I ever heard-and I have heard several men who ranked among the first orators of the nation. Great genius always contradicts itself. There is no great genius without a tincture of madness. The partition between great genius and insanity is very thin in places, and at times liable to be broken down altogether. No man ever travels through life (if he lives to middle age) with an unvarying character, and least of all a great genius. Change of environment insensibly works a change of character.

${ }^{1}$ Annals of Iowa, v. 10 , p. 320. 
Dean was a great, a very great, natural genius and was possessed of the weaknesses that belong to such geniuses. The total absence of the sense of propriety, the utter disregard of almost all of the conventional rules of society, coupled with his gormandizing propensities, and indifference to personal cleanliness had the effect to obscure his great genius, and to cause him to be regarded by many as a low, vulgar fellow, and unworthy of the applause and esteem his genius deserved.

We must overlook and forgive many things in a great genius that we would not forgive in the ordinary man. Great genius must be measured by the standard that belongs to great genius, and not by the standard by which we measure the mediocre man. But the public mind is not governed by this rule; it commonly dwells more on the weaknesses and follies of men than on the greatness of their achievements. If Dean's early environments had been of a different order from what they were many of the eccentricities that marred his genius would have disappeared.

I have read the arguments of some eminent authors and listened to the reasoning of some able divines in support of the immortality of the soul, but the most powerful, persuasive and convincing reasoning on that subject $I$ ever heard or read was from Dean when preaching the funeral sermon of John R. Wright (Uncle Sin Wright's son, who was a student in our law office and died in Keosauqua). With a diction as copious and elegant as Macaulay's, and a power of reasoning equalling if not excelling Daniel Webster's, he discoursed for two hours without a break in the high and elevated tone befitting his subject, which for him was unusual, for he seemed to delight in inserting a blot in his most finished discourses.

But I set out to do nothing more than thank and congratulate you for your admirable delineation of Dean's character. Both Wright and Knapp abhorred him, the one on personal and the other on political grounds, and while I disliked many things he said and did, I always regarded him as a transcendent natural orator, which he undoubtedly was. John R. Wright (the Judge's brother) said of Dean, "It is a pity so great a man should be so big a fool," and this remark is a brief but tolerably accurate biography of the man. You have done justice-and no more-to his memory.

Yours truly, HENRY C. CALDWELL. 
Copyright of Annals of Iowa is the property of State of Iowa, by \& through the State Historical Society of Iowa and its content may not be copied or emailed to multiple sites or posted to a listserv without the copyright holder's express written permission. However, users may print, download, or email articles for individual use. 